\title{
DAMPAK PANDEMI COVID-19 TERHADAP LOYALITAS PELANGGAN PADA MCDONALD'S CABANG SHINTA KARAWACI
}

\author{
Andres Dharma Nurhalim \\ Sekolah Tinggi Ilmu Ekonomi \\ Wiyatamandala andres@wym.ac.id
}

\begin{abstract}
The fast food industry is one of the sectors affected by the COVID-19 pandemic. The prohibition of large-scale social interaction in the community, such as holding meetings during the Large-Scale Social Restrictions (PSBB) established by each region, also contributed to a sharp decline in food and beverage sales. The average result of the COVID-19 pandemic impact variable questionnaire (X) at McDonald's Shinta Karawaci Branch was $68 \%$ in the good category. Of all the indicators of the statement, it can be seen that the lowest indicator is "Is the pandemic affecting your income" with a result of 52\%, which can be seen from the general description of the respondents of McDonald's customers at Shinta Karawaci Branch, most of whom are private employees. The average result of the questionnaire total Customer Loyalty $(Y)$ at McDonald's Shinta Karawaci Branch is $71.8 \%$ which is included in the good category. Of all these indicators, there is one indicator that has the smallest value, namely "Customers have a desire to recommend McDonald's Shinta Karawaci Branch to others". From the results of observations and interviews conducted, this is caused by several factors, one of which is the price of products offered by McDonald's Shinta Karawaci Branch which is in the upper middle category and Shinta Karawaci Branch's McDonald's outlets are still not evenly distributed, there are only a few in the city center. big. From the results of simple linear regression analysis, it is known that the influence of variable X for the COVID-19 pandemic has no effect on customer loyalty at McDonald's Shinta Karawaci Branch, variable Y.
\end{abstract}

Keyword: Pandemic Impact, Customer Loyalty

\begin{abstract}
ABSTRAK
Industri makanan cepat saji merupakan salah satu sektor yang terkena dampak pandemi COVID-19. Pelarangan interaksi sosial dalam skala besar di masyarakat, seperti mengadakan pertemuan pada masa Pembatasan Sosial Berskala Besar (PSBB) yang ditetapkan masing-masing daerah, juga turut menyumbang penurunan tajam penjualan makanan dan minuman. Hasil ratarata total kuesioner variabel dampak pandemi (X) COVID-19 di McDonald Cabang Shinta Karawaci adalah 68\% dalam kategori baik. Dari seluruh indikator pernyataan tersebut terlihat bahwa indikator yang paling rendah adalah "Apakah pandemi mempengaruhi pendapatan Anda" dengan hasil sebesar 52\%, yang dapat dilihat dari gambaran umum responden pelanggan McDonald Cabang Shinta Karawaci yang sebagian besar adalah pegawai swasta. Hasil rata-rata kuisioner total Customer Loyalty (Y) di McDonald Cabang Shinta Karawaci adalah 71,8\% yang termasuk dalam kategori baik. Dari semua indikator tersebut, ada satu indikator yang memiliki nilai terkecil
\end{abstract}


yaitu "Pelanggan memiliki keinginan untuk merekomendasikan McDonald Cabang Shinta Karawaci kepada orang lain". Dari hasil observasi dan wawancara yang dilakukan, hal ini disebabkan oleh beberapa faktor salah satunya adalah harga produk yang ditawarkan oleh McDonald Cabang Shinta Karawaci yang berada pada kategori menengah ke atas dan gerai McDonald Cabang Shinta Karawaci masih belum merata, hanya terdapat beberapa di pusat kota besar. Dari hasil analisis regresi linier sederhana diketahui bahwa pengaruh variabel $(\mathrm{X})$ pandemi COVID-19 tidak berpengaruh terhadap loyalitas pelanggan McDonald Cabang Shinta Karawaci variabel Y.

Kata Kunci: Dampak Pandemi, Loyalitas Pelanggan

\section{PENDAHULUAN}

Saat ini dunia sedang terganggu oleh wabah virus Corona. Virus Corona adalah bagian dari keluarga besar virus penyebab penyakit pernapasan mulai dari gejala ringan sampai berat. Corona Virus Diseases 2019 (COVID-19) sendiri adalah penyakit jenis baru yang belum pernah diidentifikasi sebelumnya pada manusia. WHO (World Health Organization) telah menetapkan Tanggal 30 Januari 2020 sebagai kedaruratan kesehatan masyarakat dunia. Indonesia melaporkan kasus pertama COVID-19 sebanyak 2 kasus / orang pada tanggal 2 Maret 2020 yang kemudian menjadi 10 orang pada tanggal 16 Maret 2020 menurut Direktorat Jenderal Pencegahan dan Pengendalian Penyakit (Kementerian Kesehatan Republik Indonesia, 2020). Menurut Kompas.com (28/03/2020), berbagai bidang, seperti sosial, ekonomi, pariwisata dan pendidikan, sangat terdampak oleh COVID-19 ini. Segala kegiatan di dalam dan luar ruangan pada semua sektor sejak tanggal 18 Maret 2020 sementara waktu ditunda demi mengurangi penyebaran corona sesuai dengan Surat Edaran (SE) yang dikeluarkan pemerintah (Catriana, 2020). Penerapan kebijakan Pembatasan Sosial Berskala Besar (PSBB) oleh pemerintah sangat berdampak besar terhadap penurunan kegiatan ekonomi. Masyarakat memiliki kecenderung menahan diri untuk melakukan konsumsi yang berlebih dan lebih memilih untuk memprioritaskan pemenuhan kebutuhan pokok. Salah satu sector yang terkena imbas kuat dari pandemic COVID-19 adalah industri makanan cepat saji. Dilarangnya interaksi sosial di masyarakat dalam jumlah besar, seperti mengadakan jamuan selama masa PSBB, pastinya sangat mempengaruhi penurunan penjualan makanan dan minuman dengan sangat tajam. Industri F\&B merupakan sektor yang krusial untuk dijaga keberlangsungannya karena 
hal ini menyangkut ketahanan pangan sebagai kebutuhan utama bagi seluruh manusia. Banyak orang yang berkecimpung dan menyandarkan nasibnya pada industri ini. Hal yang sama terjadi dalam industri minuman karena permintaan masih fluktuatif tetapi stok pada pasaran relatif masih aman. Hal ini terjadi karena proses produksi telah dilakukan di awal tahun untuk memenuhi kebutuhan menjelang bulan puasa dan Idul Fitri sehingga stok yang dipakai masih menggunakan bahan baku sebelumnya. Peran pemerintah dan segenap stakeholders diperlukan untuk menghadapi masa yang sulit ini dengan memperhatikan kebutuhan masyarakat. McDonald Cabang Shinta Karawaci adalah franchise makanan cepat saji yang berasal dari Amerika yang banyak tersebar banyak di wilayah Indonesia. Di saat kekhawatiran terhadap COVID-19 meningkat, pedagang mikro, seperti pedagang kaki lima (PKL) dan pedagang keliling (penjual jamu, sayuran, makanan, minuman), akan sangat terdampak pada kunjungan dan pesanan dari konsumen. Bisnis transportasi umum, pariwisata, perhotelan, pusat

\section{TELAAH LITERATUR}

\section{Loyalitas Pelanggan}

Loyalitas pelanggan merupakan perbelanjaan, dan pedagangan offline yang hanya berfokus pada kunjungan langsung konsumen, terdampak perkembangannya bahkan mengalami penururan selama masa pandemi COVID-19. Pandemi COVID-19 ini memiliki efek yang sangat besar pada keberlangsungan industri $\mathrm{F} \& \mathrm{~B}$, terutama bagaimana para pelaku usaha dapat bertahan hidup pada masa kondisi yang serba tidak pasti. Semuanya telah berubah dan berbeda dengan yang sebelumnya sehingga harus dapat membiasakan dengan segala perubahan yang terjadi, terutama dalam menyikapi perubahan perilaku dan konsumsi konsumen. Dan juga setelah diberlakukannya New Normal (Normal Baru / Kenormalan Baru) yang tentu berbeda lagi dengan keadaaan normal pada sebelumnya (Prakoso, 2020). Penelitian ini bertujuan menemukan dan menganalisa seberapa besar dampak pandemi COVID-19 berpengaruh terhadap kegiatan bisnis dan loyalitas pelanggan di Industri makanan cepat saji, yaitu di McDonald Cabang Shinta Karawaci.

komitmen pelanggan yang bertahan 
secara mendalam untuk berlangganan kembali atau melakukan pembelian ulang produk atau jasa yang terpilih secara konsisten di masa yang akan datang, walaupun pengaruh situasi dan usaha pemasaran memiliki potensi pada perubahan perilaku. Menurut Morais dalam (Sangadji \& Sopiah, 2013), loyalitas pelanggan adalah komitmen pelanggan terhadap suatu brand toko atau supplier, berdasarkan sikap yang sangat positif dan tercermin dalam pembelian ulang yang konsisten. Loyalitas pelanggan dalam konteks pemasaran jasa sebagai tanggapan yang terkait kuat dengan janji untuk memegang teguh komitmen yang mendasari kontinuitas relasi. Hal ini biasanya tercermin dalam pembelian berkelanjutan dari penyedia jasa yang sama atas dasar dedikasi dan kendala pragmatis (Sangadji \& Sopiah, 2013). Menjaga pelanggan tetap senang dan loyal adalah tantangan bagi perusahaan dan merupakan cara yang paling tepat untuk bertahan dalam persaingan. Menurut (Hasan, 2014), loyalitas pelanggan adalah orang yang membeli secara teratur dan berulangulang. Mereka yang secara terusmenerus dan berulang untuk datang ke suatu tempat yang sama demi memenuhi keinginannya dengan memiliki suatu produk atau jasa dan membayar produk tersebut. Berdasarkan beberapa definisi dari beberapa ahli di atas, dapat disimpulkan bahwa loyalitas pelanggan adalah orang yang membeli produk atau jasa yang sama secara teratur, berulang, dan terus- menerus untuk memuaskan keinginannya dengan memiliki suatu produk atau mendapatkan suatu jasa dan membayar produk tersebut. Banyak perilaku loyal yang ditunjukan oleh pelanggan terhadap suatu produk atau jasa yang mereka sukai. Menurut (Tjiptono \& Chandra, 2016), ada empat jenis loyalitas pelanggan yaitu:

1. No Loyalty (Tanpa Loyalitas) Pelanggan yang dikatakan pelanggan tanpa loyalitas adalah pelanggan yang tidak mempunyai atau mengembangkan loyalitas terhadap produk atau jasa dengan beberapa alasan, yang membuat pelanggan tidak akan pernah menjadi loyal. Secara umum perusahaan harusnya menghindari suatu kelompok pelanggan yang masuk dalam kategori tanpa loyalitas untuk dijadikan target pasar.

2. Inertia Loyalty (Loyalitas yang Lemah): Loyalitas yang lemah merupakan hasil dari keterkaitan lemah yang digabung dengan 
pembelian ulang tinggi. Pelanggan yang memiliki loyalitas yang lemah ini biasanya melakukan pembelian produk dan jasa karena sudah terbiasa atau karena sering menggunakan produk tersebut. Seperti contohnya, pembelian air galon yang dilakukan konsumen di dekat rumahnya. Hal ini membuat mereka dapat saja beralih ke produk pesaing yang lebih baik menurut mereka.

3. Latent Loyalty (Loyalitas Tersembunyi): Loyalitas tersembunyi merupakan tingkat preferensi yang relatif tinggi yang digabung dengan tingkat pembelian berulang yang rendah. Disini, yang menentukan pembelian ulang adalah pengaruh situasi dan sikap. Seperti contohnya, ayah dalam satu keluarga menyukai makanan tradisional, tetapi karena seluruh anggota keluarga lain lebih menyukai fast food, maka keluarga tersebut memilih untuk

\section{Faktor-Faktor yang Mempengaruhi}

\section{Loyalitas Pelanggan}

a. Kepuasan pelanggan

Pelanggan akan puas jika perusahaan dapat memberikan service yang melebihi ekspektasi pelanggan. Pelanggan yang puas tentunya akan lebih sering berkunjung ke restoran fast food. Perusahaan dapat mengatasi loyalitas tersembunyi ini dengan cara memahami faktor situasi yang berkontribusi pada loyalitas tersembunyi itu.

4. Premium Loyalty (Loyalitas Premium): Loyalitas premium akan terjadi jika ada suatu tingkat ketertarikan yang tinggi terhadap produk atau jasa yang berjalan selaras dengan aktivitas pembelian kembali. Loyalitas premium ini merupakan jenis loyalitas yang sangat diharapkan perusahaan. Dengan tingkat preferensi yang tinggi tersebut, konsumen umumnya merasa bangga karena menemukan dan menggunakan produk atau jasa tersebut dan akan dengan senang hati memberikan informasi seputar produk atau jasa berdasarkan pengalaman mereka kepada keluarga, teman atau pihak lainnya.

mempunyai loyalitas yang lebih tinggi terhadap produk dibandingkan pada pelanggan yang tidak puas.

b. Retensi Pelanggan

Retensi pelanggan adalah lamanya 
hubungan dengan pelanggan. Tingkat retensi pelanggan adalah presentase pelanggan yang telah memenuhi sejumlah pembelian berulang selama periode waktu yang terbatas.

c. Migrasi Pelanggan

Perpindahan pelanggan pada merek lain yang terus terjadi walaupun pelanggan telah puas dengan produk atau jasa bahkan dengan program

\section{METODOLOGI PENELITIAN}

Penelitian ini menggunakan kuantitatif deskriptif untuk mencapai tujuan penelitian dengan metode yang digunakan metode pengumpulan data penelitian yang digunakan adalah nonprobability sampling, aksidential sampling. Kuesioner dibagikan kepada tamu yang sudah pernah membeli di McDonald Cabang Shinta Karawaci minimal sebanyak 1 kali semasa pandemi COVID-19. Analisa data dalam penelitian menggunakan SPSS. Langkah awal yang dilakukan adalah melakukan uji validitas dan realibilitas. Dalam perhitungan data, peneliti menggunakan mean atau rata- rata. Metode pengumpulan data yang digunakan adalah.

1. Kuesioner

Kuesioner menurut (Sugiyono, 2014) adalah suatu cara loyalitas yang diberikan suatu perusahaan.

d. Antusiasme Pelanggan

Loyalitas tidak hanya berada dalam pikiran, mengingat danmenggunakan produk, mereferensikan dan merekomendasikan pemakaian kepada orang lain. Akan tetapi juga telah menjadi bagian dan diri pelanggan itu seutuhnya

pengumpulan data dengan menyebarkan pertanyaan kepada responden dan responden akan memberikan respon terhadap pertanyaan tersebut. Pemilihan teknik kuesioner untuk memperoleh data yang akurat secara langsung dari orang-orang yang akan dimintai data.

2. Dokumentasi

Menurut (Arikunto, 2006), dokumentasi adalah metode pengumpulan data yang digunakan peneliti untuk meneliti benda-benda tertulis, seperti buku, majalah, dokumen, peraturan, notulen rapat, catatan harian, dan lain-lain.

3. Populasi

Populasi adalah wilayah generalisasi yang terdiri dari objek atau subjek yang mempunyai kualitas dan 
karakteristik yang telah ditetapkan oleh peneliti agar dipelajari yang kemudian diambil kesimpulannya (Sugiyono, 2009). Populasi dalam penelitian ini adalah orang-orang yang pernah berkunjung minimal 1 kali ke McDonald Cabang Shinta Karawaci. Populasi menurut (Kuncoro, 2003) merupakan kelompok elemen yang lengkap dan biasanya berupa orang, objek, transaksi, atau kejadian yang dimana penulis tertarik untuk menelitinya.

4. Sampel

Sampel adalah bagian dari jumlah dan karakteristik, akibat dari keterbatasan tertentu maka peneliti dapat memakai sejumlah contoh dari populasi yang dianggap mewakili atau representatif dari populasi tersebut (Sugiyono, 2009). Dengan kata lain sampel sendiri adalah bagian kecil dari populasi yang menggambarkan keseluruhan populasi tersebut. Teknik sampling yang digunakan adalah teknik sampling nonprobabilitas, yaitu

\section{Metode Analisis Data}

Teknik analisis data yang digunakan untuk menjawab masalah yang dirumuskan dalam penelitian adalah Uji Mean yang mana penggunaan mean atau suatu teknik pengambilan sampel secara tidak acak (non- random sampling). Saat melakukan pemilihan satuan sampling tidak akan dilibatkan unsur peluang, sehingga tidak diketahui unsur peluang sesuatu unit sampling terpilih ke dalam sampling. Unsur populasi yang terpilih menjadi sampel dapat disebabkan karena kebetulan atau oleh karena faktor lain yang sebelumnya sudah direncanakan oleh peneliti. Penentuan jumlah sampel minimal mengacu pada pernyataan (Hair, Black, Babin, \& Anderson, 2010) bahwa banyaknya sampel sebagai responden harus disesuaikan dengan banyaknya indikator pertanyaan yang digunakan pada kuesioner. dengan asumsi ' $\mathrm{n}$ x 5' observed variable (indikator) sampai dengan ' $\mathrm{n}$ x 10' observed variable (indikator). Dengan kata lain ialah Sample $=$ Jumlah Indikator x $10=11$ $\mathrm{x} 10=110$ responden .

rata-rata digunakan dalam perhitungan data. Hasil jawaban yang diperoleh dengan cara perhitungan di atas, dipakai untuk mengembangkan kesimpulan, 
yaitu:

$0 \%-25 \%=$ Tidak Baik

$26 \%-50 \%=$ Cukup Baik

\section{Uji Validitas}

Uji validitas menggunakan analisis korelasi pearson, yaitu keputusan mengetahui valid tidaknya butir instrumen. Jika pada tingkat signifikan

\section{Regresi Linear Sederhana}

Regresi linear sederhana adalah hubungan secara linear antara satu variabel independen $(\mathrm{X})$ dengan variabel dependen (Y). Analisis ini digunakan agar dapat mengetahui arah hubungan antara variabel independen dengan variabel dependen, positif atau negatif,
$51 \%-75 \%=$ Baik

$76 \%-100 \%=$ Sangat Baik

$5 \%$ nilai $\mathrm{r}$ hitung $>\mathrm{r}$ tabel, maka dapat disimpulkan bahwa butir instrument tersebut adalah valid.

dan untuk memprediksi nilai darivariabel dependen apabila nilai variabel independen mengalami kenaikan atau penurunan nilai. Data yang digunakan biasanya berskala interval atau rasio. Rumus dari dari analisis regresi linear sederhana adalah sebagai berikut:

$\mathrm{Y}=\mathrm{a}+\mathrm{bX}$

Keterangan:

$\mathrm{Y}=$ subyek dalam variabel dependen

yang didasarkan pada perubahan variabel yang diprediksi $\mathrm{a}=$ harga $\mathrm{Y}$ ketika harga independen. Bila (+) maka arah garis $\mathrm{X}=0$ (harga konstan) naik dan bila (-) maka arah garis turun $\mathrm{b}=$ angka arah atau koefisien regresi, $\mathrm{X}=$ subjek pada variabel independen yang menunjukkan angka peningkatan yang mempunyai nilai tertentu ataupun penurunan variabel dependen

\section{Analisa Mean}

Tabel 4.5 Analisa Mean Dampak Pandemi COVID-19

\begin{tabular}{|c|l|c|}
\hline No. & \multicolumn{1}{|c|}{ Pertanyaan } & Hasil \\
\hline 1 & Apakah pandemi berpengaruh terhadap pendapatan Anda & $52 \%$ \\
\hline 2 & Apakah pandemi berpengaruh kepada minat pembelian Anda & $74 \%$ \\
\hline 3 & Apakah pandemi berpengaruh terhadap keputusan pembelian Anda & $79 \%$ \\
\hline & Rata-rata & $\mathbf{6 8 \%}$ \\
\hline
\end{tabular}


Berdasarkan tabel 4.5 diketahui bahwa hasil rata-rata total kuesioner variabel Dampak Pandemi COVID- 19 (X) di McDonald Cabang Shinta Karawaci adalah sebesar $68 \%$ yang tergolong dalam kategori baik. Dari seluruh indikator pernyataan dapat di lihat bahwa indikator paling rendah terdapat pada "Apakah pandemi berpengaruh terhadap pendapatan Anda" dengan hasil 48\%, dimana dapat dilihat dari hasil gambaran umum responden pelanggan McDonald
Cabang Shinta Karawaci yang paling banyak merupakan pegawai swasta, hal ini yang menjadikan faktor pelanggan McDonald Cabang Shinta Karawaci tidak mengalami pengaruh dari dampak COVID-19. Karena para pelanggan McDonald Cabang Shinta Karawaci lebih banyak dari kategori pekerja swasta yang perusahaanya masih tetap berjalan selama COVID-19 dan sebagian menerapkan WFH (Work From Home)

Tabel 4.6 Analisa Mean Loyalitas Pelanggan

\begin{tabular}{|c|l|c|}
\hline No. & \multicolumn{1}{|c|}{ Pertanyaan } & Hasil \\
\hline 1 & $\begin{array}{l}\text { Pihak McDonald Cabang Shinta Karawaci dapat melihat dan mengatasi } \\
\text { segala } \\
\text { kebutuhan, harapan, maupun permasalahan yang dihadapi oleh } \\
\text { pelanggan }\end{array}$ & $70 \%$ \\
\hline 2 & $\begin{array}{l}\text { Jenis produk yang dijual oleh McDonald Cabang Shinta Karawaci } \\
\text { Indonesia memiliki kualitas atau kesempurnaan seperti yang seharusnya } \\
\text { atau sesuai } \\
\text { dengan yang di janjikan }\end{array}$ & $63 \%$ \\
\hline 3 & $\begin{array}{l}\text { Pelanggan tidak khawatir dengan pihak McDonald Cabang Shinta } \\
\text { Karawaci } \\
\text { dalam melakukan transaksi }\end{array}$ & $\begin{array}{l}\text { Pihak McDonald Cabang Shinta Karawaci dapat memberikan rasa } \\
\text { puas kepada pelanggan dalam memperhatikan dan meningkatkan fungsi } \\
\text { dari segala } \\
\text { fasilitas dan sumber daya yang dimiliki }\end{array}$ \\
\hline 5 & $\begin{array}{l}\text { Pihak McDonald Cabang Shinta Karawaci mampu membuat } \\
\text { pelanggan } \\
\text { berkomitmen untuk melakukan pembelian berulang }\end{array}$ & $69 \%$ \\
\hline 6 & $\begin{array}{l}\text { Pelanggan memiliki keinginan untuk merekomendasikan McDonald } \\
\text { Cabang } \\
\text { Shinta Karawaci kepada orang lain }\end{array}$ & $\begin{array}{l}\text { Pelanggan tidak memiliki keinginan untuk berpindah kepada pesaing } \\
\text { McDonald Cabang Shinta Karawaci }\end{array}$ \\
\hline 7
\end{tabular}




\begin{tabular}{|r|l|c|}
\hline 8 & $\begin{array}{l}\text { Pelanggan puas terhadap seluruh penjualan yang diberikan McDonald } \\
\text { Cabang } \\
\text { Shinta Karawaci }\end{array}$ & $75 \%$ \\
\hline Rata-rata & $\begin{array}{c}\mathbf{7 1 , 8} \\
\mathbf{\%}\end{array}$ \\
\hline
\end{tabular}

Berdasarkan tabel 4.6 diketahui bahwa hasil rata-rata total kuesioner Loyalitas Pelanggan (Y) di McDonald Cabang Shinta Karawaci sebesar $71,8 \%$ yang tergolong dalam kategori baik. Dari seluruh indikator terdapat satu indikator yang memiliki nilai paling kecil yaitu adalah Pelanggan memiliki keinginan untuk merekomendasikan perusahaan kepada orang lain dari hasil observasi dan wawancara yang dilakukan hal ini disebabkan karena adanya beberapa faktor, salah satunya adalah harga dari produk yang di tawarkan pihak McDonald Cabang Shinta Karawaci tergolong dalam kategori menengah ke atas dan outlet McDonald Cabang Shinta Karawaci juga masih tidak menyebar rata yang hanya ada beberapa di pusat kota besar.

\section{Uji Reliabilitas}

Tabel 4.7 Hasil dari Uji Reliabilitas (Reliability Statistics)

\begin{tabular}{|c|c|}
\hline $\begin{array}{c}\text { Cronbach' } \\
\boldsymbol{s}\end{array}$ & $\begin{array}{c}\text { Nof } \\
\text { Items }\end{array}$ \\
\hline Alpha & \\
\hline 0,728 & 11 \\
\hline
\end{tabular}

Berdasarkan tabel 4.7, dapat dilihat bahwa hasil uji reliabilitas yang menggunakan cronbach's alpha ini menunjukkan hasil

\section{Uji Validitas}

Uji validitas berhubungan dengan seberapa jauh alat ukur yang digunakan dapat mengukur apa yang hendak diukur. Dari jumlah sampe 110 orang, diperoleh, yang reliabel atau dapat diandalkan yang dapat dilihat dari nilai tidak ada nilai yang berada di bawah 0,6 .

$\mathrm{t}$ tabel $=1,66$, dan $\mathrm{r}$ tabel $=0,17$. Selanjutnya kita akan membandingkan $r$ tabel dengan $r$ hitung yang telah kita peroleh. 
Tabel 4.8 Hasil dari Uji Validitas

\begin{tabular}{|l|l|l|l|}
\hline No. & Pertanyaan & $\begin{array}{c}\text { Corrected } \\
\text { Item-Total } \\
\text { Correlation }\end{array}$ & Keterangan \\
\hline 1 & $\mathrm{X} 1$ & 0,313 & Valid \\
\hline 2 & $\mathrm{X} 2$ & 0,372 & Valid \\
\hline 3 & $\mathrm{X} 3$ & 0,199 & Valid \\
\hline 4 & $\mathrm{Y} 1$ & 0,629 & Valid \\
\hline 5 & $\mathrm{Y} 2$ & 0,874 & Valid \\
\hline 6 & $\mathrm{Y} 3$ & 0,852 & Valid \\
\hline 7 & $\mathrm{Y} 4$ & 0,849 & Valid \\
\hline 8 & $\mathrm{Y} 5$ & 0,868 & Valid \\
\hline 9 & $\mathrm{Y} 6$ & 0,577 & Valid \\
\hline 10 & $\mathrm{Y} 7$ & 0,474 & Valid \\
\hline 11 & $\mathrm{Y} 8$ & 0,774 & Valid \\
\hline
\end{tabular}

Tabel 4.9 Hasil dari Uji Regresi Linear Sederhana \& Uji Hipotesis

\begin{tabular}{|l|l|l|l|l|l|}
\hline \multirow{3}{*}{ Model } & \multicolumn{2}{|c|}{$\begin{array}{c}\text { Unstandardize } \\
\text { Coefficients }\end{array}$} & $\begin{array}{c}\text { Standardized } \\
\text { Coefficients }\end{array}$ & t & Sig. \\
\cline { 2 - 6 } & B & Std. Error & Beta & & \\
\hline $\begin{array}{l}1 \\
(\text { Constant })\end{array}$ & 13,217 & 3,119 & & 10,441 &, 000 \\
\hline \multicolumn{1}{|c|}{ X } &,- 018 &, 313 &,- 006 &,- 058 &, 519 \\
\hline
\end{tabular}

Dependent Variable: $Y$

Angka konstan dari Unstandardized Coefficients adalah sebesar 13,217 nilai ini berarti jika tidakada pandemi (x) maka nilai loyalitas adalah 13,217. Angka Koefisien Regresi nilainya sebesar 0,018. Angka ini mengandung arti bahwa setiap penambahan $1 \%$ nilai pandemi

\section{Uji Hipotesis}

Ho: Tidak ada pengaruh antara pandemi dengan loyalitas pelanggan.

Ha: Ada pengaruh antara pandemi
(X), maka loyalitas pelanggan akan meningkat sebesar -0,018. Karena nilai koefisien regresi bernilai minus, maka dapat dikatakan bahwa pandemi berpengaruh negatif terhadap loyalitas pelanggan sehingga persamaan regresinya adalah $\mathrm{Y}=13,217-0,018 \mathrm{X}$.

dengan loyalitas pelanggan.

Jika nilai Sig. lebih kecil dari probabilitas 0,05 mengandung arti bahwa ada 
pengaruh antara pandemi dengan loyalitas pelanggan. Sebaliknya jika nilai Sig. lebih besar dari probabilitas 0,05 tidak ada pengaruh antara pandemi dengan loyalitas pelanggan. Berdasarkan output coefficeints diketahui nilai Sig.

\section{SIMPULAN}

Kesimpulan yang dapat diambil dari penelitian ini adalah sebagai berikut:

1. Hasil rata-rata total kuesioner variabel Dampak Pandemi COVID19 (X) di McDonald Cabang Shinta Karawaci adalah sebesar $68 \%$ yang masuk ke dalam kategori baik. Dari seluruh indikator pernyataan dapat dilihat bahwa indikator paling rendah terdapat pada "Apakah pandemi berpengaruh terhadap pendapatan Anda" dengan hasil 48\% dimana dapat dilihat dari hasil gambaran umum responden pelanggan McDonald Cabang Shinta Karawaci yang paling banyak merupakan pegawai swasta. Hal ini yang menjadikan factor pelanggan McDonald Cabang Shinta Karawaci tidak mengalami pengaruh dari dampak COVID-19. Karena para pelanggan McDonald Cabang Shinta Karawaci lebih banyak dari kategori pekerja swasta yang perusahaanya masih tetap berjalan selama COVID19 dan sebagian menerapkan WFH (Work From Home). sebesar 0,519 lebih besar dari probabilitas 0,05. Sehingga dapat disimpulkan bahwa tidak ada pengaruh antara pandemi dengan loyalitas pelanggan.

2. Hasil rata-rata total kuesioner Loyalitas Pelanggan (Y) di McDonald Cabang Shinta Karawaci adalah sebesar $71,8 \%$ yang tergolong dalam kategori baik. Dari seluruh indikator terdapat satu indikator yang memiliki nilai paling kecil yaitu "Pelanggan memiliki keinginan untuk merekomendasikan McDonald Cabang Shinta Karawaci kepada orang lain" dari hasil observasi dan wawancara yang dilakukan. Hal ini disebabkan oleh karena beberapa faktor, yaitu harga dari produk yang ditawarkan pihak McDonald Cabang Shinta Karawaci tergolong dalam kategori menengah ke atas dan outlet McDonald Cabang Shinta Karawaci juga masih tidak menyebar rata (hanya ada beberapa di pusat kota besar).

3. Dari hasil analisa regresi linear sederhana didapatkan bahwa dampak pandemi COVID-19 variabel $\mathrm{X}$ tidak berpengaruh terhadap Loyalitas pelanggan Indonesia variable $\mathrm{Y}$. 
Penulis memiliki beberapa saran yang dapat dipertimbangkan berdasarkan hasil penelitian ini, yaitu:

1. Pihak McDonald Cabang Shinta Karawaci Indonesia harus memiliki lebih banyak ragam produk yang dapat dinikmati dari berbagai kalangan baik kalangan menengah sampaimenengah ke atas. Dan juga pilihan ukuran minuman yang lebih cocok dan diminati oleh keluarga karena WFH yang sedang

\section{DAFTAR PUSTAKA}

Arikunto, S. (2006). Prosedur Penelitian Suatu Pendekatan Praktik (6th ed). Jakarta: Rineka Cipta.

Catriana, E. (2020, Februari 28). Dampak virus corona BI sebut tiga sektor ini akan terganggu. Retrieved from Kompas.com:

https://money.kompas.com/read/20 20/02/28/182027526/dampakvirus- corona-bi-sebut-tiga-sektorini-akan-terganggu

Fandy, Tjiptono, Greforius, \& Chandra. (2016). Pemasaran Jasa (Prinsip, Penerapan, dan Penelitian), Yogyakarta: Andi. Yogyakarta: Andi .

Gunawan, K., \& Djati, S. P. (2011). Kualitas layanan dan loyalitas pasien: studi pada rumah sakit berlangsung adalah ukuran 1 liter.

2. Pihak McDonald Cabang Shinta Karawaci harus melakukan promosi sesuai dengan tren yang sedang berlangsung dengan banyak menghadirkan potongan harga atau cashback yang bekerjasama dengan pihak ke-3 seperti menghadirkan metode pembayaran yang sedang banyak diminati berbagai kalangan (Ovo, Gopay, Shopeepay).

umum swasta di kota singarajabali. Jurnal Manajemen dan Kewirausahaan, 13(1), 32-39. doi:https://doi.org/10.9744/jmk.13. 1.32-39

Hair, J. F., Black, B., Babin, B. J., \& Anderson, R. E. (2010). Multivariate data analysis (7thed.). London: Pearson Education Inc.

Hasan, A. (2014). Marketing dan KasusKasus Pilihan. Yogyakarta: CAPS. Kementerian Kesehatan Republik Indonesia. (2020). Pedoman pencegahan dan pengendalian coronavirus disease (COVID-19) (5th ed.). Jakarta: Direktorat Jenderal Pencegahan dan Pengendalian Penyakit, Kementerian Kesehatan Republik 
Indonesia.

Kuncoro, M. (2003). Metode riset untuk bisnis dan ekonomi. . Jakarta: Erlangga.

Prakoso, F. A. (2020). Dampak Coronavirus Disease (Covid-19) Terhadap Industri Food \& Beverages. Jurnal Manajemen Bisnis, Vol.33 No.2, 1-6.

Sangadji, E. M., \& Sopiah. (2013). Perilaku konsumen: Pendekatan praktis disertai himpunan jurnal penelitian. Andi. Jakarta: Andi .

Sugiyono. (2009). Metode Penelitian
Kunatitatif Kualitatif dan $R \& D$. Bandung: Alfabeta.

Sugiyono. (2014). Metode Penelitian Kuantitatif, kualitatif dan $R \& D$. Bandung: Alfabeta.

Taufik, \& Ayuningtyas, E. A. (2020). Dampak pandemi covid-19 terhadap bisnis dan eksistensi platform online. Jurnal Pengembangan Wiraswasta, 22(1), 21-32. doi:http://doi.org/10.33370/jpw.v2 $2 \mathrm{i} 01.389$ 